\title{
Orbital plasma cell myeloma
}

\author{
R. M. MGFADZEAN \\ Neurological Unit, Northern General Hospital, Edinburgh
}

Orbital plasma cell myeloma is a rare condition. In a review of 222 intraorbital tumours, Forrest (1949) found only one case, and Offret (195I) reported two cases in a series of 676 orbital tumours. Clarke (1953) emphasized the differentiation between the plasma cell myeloma of myelomatosis and the benign plasma cell tumour produced by chronic inflammation. The present report concerns a case presenting with orbital and neurological signs and complicated by renal failure.

\section{Case report}

A 59-year-old housewife complained of drooping of the left upper eyelid for 6 months, accompanied by tingling on the left side of the jaw. She felt rather tired.

\section{Examination}

There was ptosis of the left upper eyelid through which a hard and craggy mass was palpable (Fig. 1 ). The left eyeball was depressed and rotated inferiorly. Diplopia occurred on looking up because of mechanical interference with the eye movements. There was an area of diminished pin-prick sensation on the left side of the chin. The skin showed a yellowish pigmentation.

Address for reprints: R. M. McFadzean, F.R.C.S., Neurological Unit, Northern General Hospital, Ferry Rd., Edinburgh EH5 2DQ

\section{Investigations}

A brain scan showed an area of increased isotope uptake seen symmetrically around the mid-line, but a left carotid angiogram performed under general anaesthesia was normal. She vomited several times during the 24 hours after the latter procedure.

Biopsy of the orbital mass was carried out 4 days later, also under general anaesthesia. Following this procedure she again vomited, became anuric, and was found to be in acute renal failure. Peritoneal dialysis was immediately instituted.

The histology of the orbital tissue showed fat and fibrous tissue infiltrated by myeloma (Fig. 2). The tumour was composed of a mixture of mature plasma cells and precursors showing variable degrees of anaplasia. Mitoses were fairly frequent.

Plasma protein electrophoresis showed a myeloma band and bone marrow examination a large number of immature plasma cells. Renal biopsy demonstrated acute tubular necrosis in association with casts, very suggestive of myeloma kidney.

\section{Treatment}

Regular haemodialysis twice weekly was instituted. Plasmapheresis was carried out and 4-day courses of Melphalan 0.25 mg./kg. daily with Prednisone $2 \mathrm{mg} . / \mathrm{kg}$. daily were given at intervals of 6 weeks (Alexanian, Haut, Khan, Lane, McKelvey, Miglione, Stuckey, and Wilson,

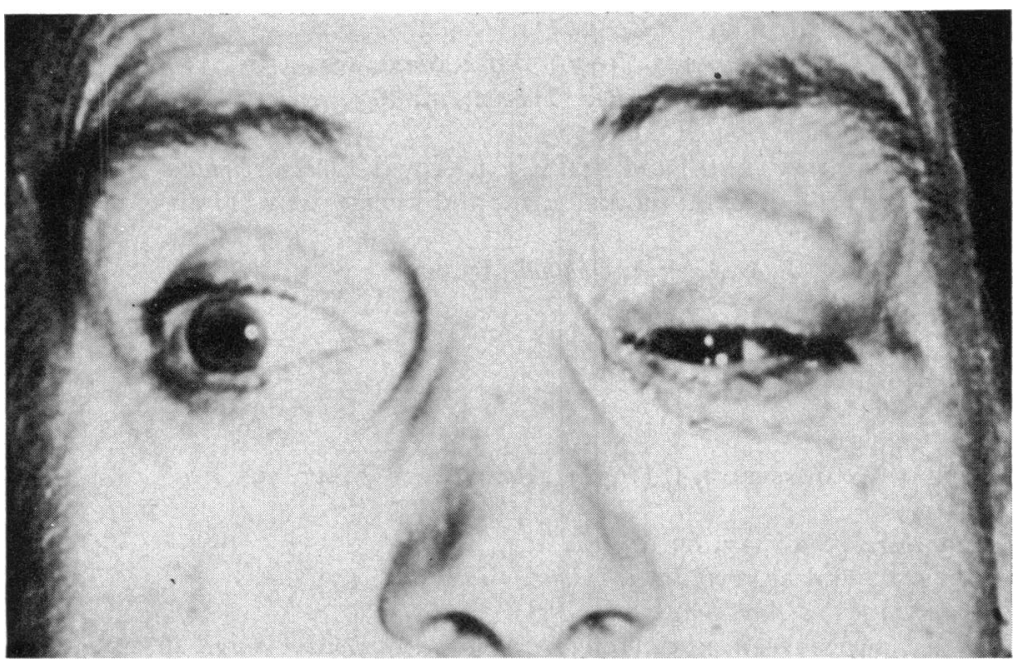




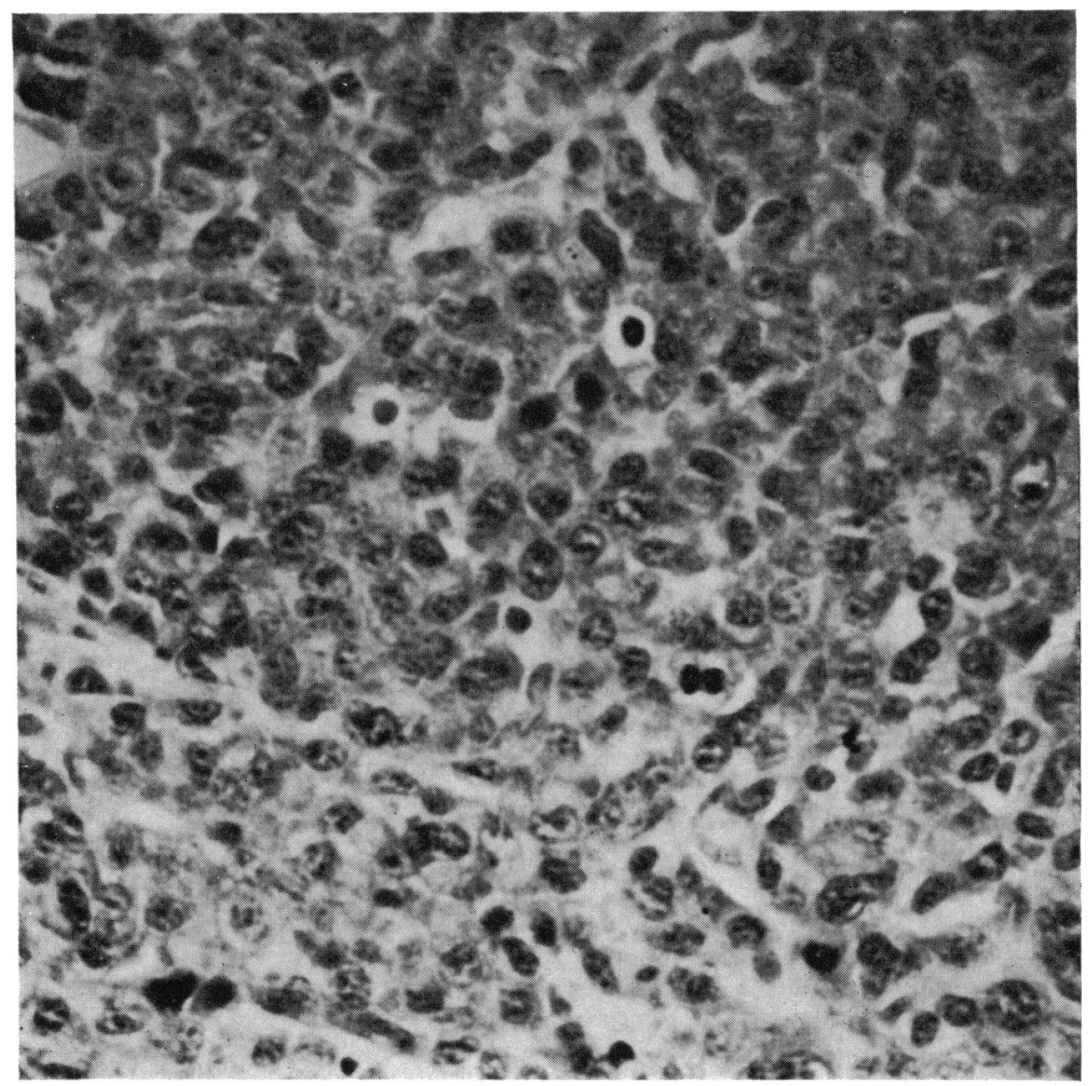

1969). The orbital lesion has been irradiated with five treatments of megavoltage $x$-ray therapy using a maximal tissue dose of 2,000 rads.

Progress

After 3 months there was an excellent response, the orbital tumour in particular regressing entirely.

\section{Discussion}

A case is reported of a rare orbital tumour. Attention is drawn to the danger of precipitating acute renal failure in this condition by administering a general anaesthetic. The dehydration before anaesthesia is thought to be responsible (Black, I97I). It is postulated that the fifth nerve disturbance was due to involvement of the greater wing of the sphenoid around the foramen ovale through which its mandibular division passes (d'Eramo and Levi, 1972).

I wish to thank Dr. C. Mawdsley and Dr. J. F. Cullen for permission to publish this case and for helpful advice in the preparation of this paper, and Dr. I. M. MacMichael for the histology. Mr. A. MacDonald kindly carried out the photography.

\section{References}

alexanian, R., haUt, A., khan, A. U., LANe, M., Mckelvey, G. M., Miglioie, P. J., Stuckey, W. J., and WILson, H. E. (1969) 7. Amer. med. Ass., 208, 1680 BLACK, D. (1972) "Renal Disease", 3rd ed., p. 439. Blackwell, Oxford ClaRKe, E. (1953) Brit. 7. Ophthal., 37, 543

D'ERAmo, N., and LeVi, M. (1972) "Neurological Symptoms in Blood Diseases", p. 204. Miller and Medcalf, Aylesbury FORREST, A. W. (1949) Arch. Ophthal. 41, I98

OFFRET, G. (I95I) "Les tumeurs primitives de l'orbite", p. 268. Masson, Paris 